\title{
CIVIC CONSCIOUSNESS DEVELOPMENT OF YOUTH IN THE CONTEXT OF EDUCATIONAL REFORMS: THE US EXPERIENCE
}

\begin{abstract}
The article analyzes the experience of patriotic education and civic consciousness of youth in the United States. The author shares his experience of training under the programme "Civic consciousness development of youth in the context of educational reforms" of the US Agency for International Development (USAID).

It has been found that the main course of civic education syllabus in the USA is the formation of political culture, legal awareness, the culture of interethnic relations, work motivation, awareness of moral values, the understanding of freedom, the culture of interethnic relations, the development of work motivation, fostering in children respect for work and realization of its role in people's life. Civic education in US schools is performed in four ways: as a school subject; as a form of interdisciplinary activities in education; as a form of extra-curricula activities; as a way of school life which develops democratic behaviour.

The article analyzes the role of public organizations in civic education of youth and defines the lines of their activities as well as a problem of low efficiency of civic education in Ukraine caused by the following reasons: conventional perceptions that civic education does not require special attention; the lack of concurrency in civic education curriculum implementation; the lack of consistency in training and professional development of civic education teachers, in sharing positive experience, coordination of activities and monitoring.
\end{abstract}

Key words: patriotic education, civic consciousness, education of youth, the United States, civil society, civic education.

\section{INTRODUCTION}

Among crucial issues of psychological and pedagogical sciences in the developed countries is the problem of patriotic education and civic consciousness development of youth in particular. In the context of resolving conflicting situations of last two years, the domestic public represented a high level of social consciousness development. However, there is a number of unsolved problems of the process in education. Today both integrated system of patriotic education and civic responsibility of the younger generations are not formed. Despite numerous events organized and held in schools as a part of patriotic education, most of them have no or little effect.

The adopted Concept of national and patriotic education (Концепція національнопатріотичного виховання дітей та молоді, 2015) also raises many questions both in scientific and educational communities, as this document does not consistently reflect the essence of the process. These phenomena require understanding and use of international experience in creating effective system of patriotic education and civic consciousness of youth.

\section{THE AIM OF THE STUDY}

The article analyzes the achievements of foreign countries in patriotic education of youth civic consciousness. The article deals with the author's experience of participating in 
"Civic consciousness development of youth in the context of educational reforms" of the US Agency for International Development (USAID) training program.

\section{THEORETICAL FRAMEWORK AND RESEARCH METHODS}

The problem of civic education in Ukraine is studied in the works of T. Aslamov, T. Bakk, O. Batischev, M. Boychuk, N. Choba, T. Kolhan, S. Kuksenko, Yu. Omelchuk. Foreign experience of civic education and the possibility of its adaptation in Ukraine is presented in researches of O. Demyanchuk, V. Dubrovsky, Ya. Hurnikevych, L. Likhnevska, Yu. Plyska, O. Zabolotna. There is a number of guidelines and programs on civic education for the Ukrainian education system based on the adopted international experience of civic education.

The study of scientific researches confirms the importance and relevance of the American experience in the field of civic education.

The main methods used are the analysis and synthesis of philosophical, pedagogical and psychological literature on civic education that allow to show the specific nature of civic education in the US and outline main approaches to its organization in education.

\section{RESULTS}

The analysis of the US experience shows that civil society operates effectively under favorable conditions, among them are well-developed social structure and democracy. Civil society is a complex and multilevel system of non-governmental relationships and establishments which includes a set of non-governmental social institutions aimed at meeting the individual and collective needs of citizens. The process of civic education in the US has its own genesis. Americans are proud of their 200-year history of democracy, which is reflected in the consistency of social processes. The structure of American civic education of young people includes civic knowledge, skills and citizenship.

Let us see how these components are implemented. The implementation of the first component, civil knowledge, is embedded in the National Civic standards and takes into account five concepts: civil life, politics and government; major US political system; the realization of the goals, values and principles of American democracy; US relations with other countries; the role of citizens in democracy.

The aim of civic education is the formation of students' political culture as a necessary basis of a person's ideological culture. Specific nature of political education is revealed in certain tasks aimed at developing political consensus scientific worldview in the multicultural society which is provided by civic education system. Legal education is a separate component of comprehensive development of personality in US schools and carried out in close connection with the political culture. The moral and legal norms that are formed in a team include the organization of every citizen's life in accordance with these rules and bring students to aquire civic consciousness, the interest to the political life of their country, legal culture and development of independent critical thought.

The main directions of civic education in the USA is the development of political culture, legal consciousness, the culture of interethnic relations, work motivation, the awareness of moral values, understanding of freedom. The most essential is the idea of multicultural education, aimed at preparing every citizen to live in a multicultural environment. That is why the American system of civic education focuses on upbringing "the citizens of the world", not being limited to ethnocentrism.

An important area of civic education is development of inter-ethnic relations, which requires tolerant communication with different ethnic groups, with respect to their culture. The success of intercultural communication depends on the participants' understanding of these differences. 
Another area of civic education is development of work motivation, foster in children respect for work and awareness of its role in people's life.

Civic skills are formed through the obligation of citizens to know their rights and perform their duties. To do this they need to have not only necessary knowledge but also acquire certain intellectual and practical skills of participation in public life.

Civic stance is formed gradually in the process of child's understanding of what is happening in the world, and leads to his development as an independent member of society, voluntary observance of behavior standards, awareness of political and economic responsibilities, participation in public events, awareness of constitutional democracy support, the recognition of human dignity. Civic stance is crucial for the proper functioning of the political system and the individual, for the development of society.

Among the basic moral values of American society there is understanding of freedom, honesty, trust, responsibility, respect, and care for other people, justice. The moral education in schools solves the problem of students' moral consciousness development; promotion of moral feelings and convictions; training habits of moral behavior; acquisition of the experience in moral relationships.

At school teachers help students to self-determine according to social and political events and not only impose certain political ideas, but also teach students various social trends.

Civic education in US schools is performed in four ways: as a school subject; as a form of interdisciplinary activities in education; as extra-curricula activities; as a school life style promoting democratic behavior (Ліхневська, 2009).

Civic education programmes are developed every year in the United States. The theoretical part of such programmes includes studying of the USA Constitution, political and government documents. Great attention is paid to civil rights and obligations. The practical part of the programme covers the management of the school community and the relationship between its members.

Civic education programmes are developed in many organizations as the government has allocated little funds over recent years, but each programme meets standard requirements specified in state standards of the Civic education. The structure of US civil society includes branching network of various voluntary associations of citizens, lobby groups, municipal communities, charitable foundations, service clubs, creative and cooperative associations, sports associations, religious, public organizations and unions. Nowadays there are about 1.5 million of non-governmental organizations (NGOs). These independent voluntary associations help people to prove individual freedom, while maintaining stable social order. Thus, civic society using citizens's activities raise their unity and solidarity.

Through non-governmental organizations Americans unite to solve local problems, such as children safety on the roads, reducing crime level, improving schoolwork (in the USA local authorities are responsible for education), increased transparency in the work of local authorities and others. Public organizations are involved in national issues including health care reform or immigration legislation reform. Some American NGOs are trying to solve global issues (for example, the Association for arms control or the Global Women's Fund).

The work of the "Confidence in democracy" program and Da Vinci "Interactive" organization is aimed at creating educational materials on civic education. The "American democracy" game was developed to teach middle school students the legislative process basics. Playing the game a student can act as a member of Parliament and participate in the creation of laws and analyze the conflicts of interests of different individuals and groups. This process teaches students to find ways of avoiding conflicts, find solution through negotiation, debate or compromise. The game has three levels, each of them can be used in 
the classroom by each student individually. Bills under consideration in the games are current and aimed at solving problems that people face in real life. The teacher can monitor the success of the players (students) and the National Conference of legislatures of the United States provides comments (Джанет Геринг, 2013).

ICivics is a nonprofit organization promoting civic education through interactive and attractive learning resources. Their educational resources empower teachers and prepare a new generation of students who will be educated and active citizens. Founded and headed by the judge Sandra Day O'Connor, iCivics gives students the necessary tools for active participation and democratization, and introduces the materials and provides support to achieve this goal. Sufficient resources include prints of lesson plans, games with prizes and digital interactive activities. With the help of iCivics games students play different social roles and have the environment to solve real problems and issues. They are based on distinct training purposes and are integrated with lesson plans and aids.

ICivics training programmes are grouped in thematic blocks according to national and comprehensive basic standards. Teachers successfully implemented iCivics in a variety of classes, and students using the program become more intelligent, interested and willing to participate in public activities and discussions than their peers. The teaching staff including more than 40000 teachers and three million students draw upon the "iCivics" game for the annual maintenance of high quality citizenship principles in training programmes. The iCivics game has been held more than ten million times all over the country. Teachers and students choose games because:

- children learn theory through practice, solving specific tasks;

- games show the results immediately (for example, the "Court" game, where the

judge evaluates your work as a lawyer);

- games always contain an element of education;

- the role of the student becomes more important;

- there are computer games or games played during the classes.

Games teach students how the election goes on; how the court system works; how the immigration system functions; how to take political decisions, etc. This is the way to develop knowledge and practical skills.

In some states they created interactive games based on conflict of group interests for adequate allocation of state budget resources. These games gained extraordinary popularity among both children and adults, because each player can try on the role of a legislator involved in the budget planning. The number of players varies and the complexity of the game depends on it. An important requirement is to achieve understanding by most participants and come to a coordinated decision. In every state the game has its specific features.

These games allow young people to understand the complexity of the legislative activity and make suggestions and wishes concerning real budget to the state administration.

A new trend in civic education of youth is offered by the "Trust in democracy" programme of State Legislature National Conference of the United States, attracting state legislators to the civic education activities. The representatives of government bodies can help young people to understand the importance of public and governmental activities, and thus encourage them to aquire necessary education to participate in life of the country.

Through the "America's legislators are back to school" programme the members of government bodies take part in the discussions, talk about their experience in the legislature, about the debates, negotiations and compromises they have to agree to achieve results in the legislative process. 
All these activities improve the efficiency of mastering the students' knowledge and understanding of political processes. Another program that has proven its efficiency, according to experts of the National Conference, is an Advisory board which attracts young people to the legislative process and teach democratic practices to the public. Such councils are currently operating only in twelve states. Also there is an interesting experience of the best students training in the state Congress for a week. Many research public organizations are involved in research evaluating the state of civic consciousness of Americans, particularly such organizations as Campaign of public schools mission, Leonora Annenberh Civic Education Institute of Annenberh Center for Public Policy of Pennsylvania University, National Conference on Citizenship, Civic Education Information and Research Center at Tufts University, and Civic Education Division of the American Bar Association (Джанет Геринг, 2013).

In Maryland a significant impact on the development of civic education is done by Maryland Civics and Law Academy (CLA) and Citizenship Law Related Education Program (CLREP) Maryland State Bar Association, which attracts young people from comprehensive schools and middle school age to studying law and civic society problems. Maryland Civics and Law Academy is an important tool to support public understanding of the courts work, increase public trust and confidence in justice. The organization supplies aids for teacher training and educational programmes for students, such as "Civic and legal activity", "One day conference dedicated to the laws", "Simulation of legal cases".

Training involves the following topics: law and justice; rights and responsibilities; freedom of speech; school of speech and laws restricting freedom of speech, power and authority. The interactive games involving judges and lawyers are used in studying process.

In The Intersection organization, high school students from low-income groups turn into leaders with the skills, ensuring their success (enter the colleges, carry out social activities, formulate and solve the problems which they encounter personally or with their communities). The only criterion for selecting students is the motivation and willingness to learn. Then the students meet three times a week, two hours a day for fourteen weeks. After completing the programme, students are treated with "College and Career" consulting service that helps to reach the goal of college education. After graduation, students can work in a "regulatory committee" where they help to determine the next programme's focus. Junior and senior students can become instructors and mentors for the next group of tenth form students. The Intersection students created a social movement, registered 118 voters and helped to adopt a law - MD Dream Act (The Intersection, 2015).

The organization implements well-known projects in Baltimore. We will focus on two of them:

1) the first project refers the possibility of studying in college for the children of immigrants, who have not yet received the official documents (the organization achieved significant results and a relevant law was adopted);

2) "235 lives", which appeared after 235 young people were unjustly killed in 2013 (the last wide-known case in which police officer was supposed to accidentally kill an African-American and the police officer was freed from accusation (the case is still open and debated in society); the goal of a programme is a job position for young people instead of a murdered young man. The organization is engaged in negotiations with business structures for youth employment.

The International Youth Foundation (IYF) invests into the unique potential of young people. The organization invests in the unique potential of young people aged from 13 to 28 and implements the following programmes: "Passport to Success", "Club of Young Volunteers", "Volunteering Day" and "Social Entrepreneurship". 
The Liberty's Promise organization supports young immigrants and encourages them to be active and conscious American citizens. The programmes they implement, Civics and Citizenship and CE-BELL, are intended to make the immigrants' experience favourable for every arriving young person and to upbring a feeling of pride and support for American ideals of democracy and freedom. The organization tries to confirm the principles of equality and democratic traditions for future generations (New Lens, 2015).

According to the survey, patriotism in the USA comes to a very high level, $85 \%$ in 2013. The organization's deputy chairman believes that the development of youth civic consciousness is not being paid enough attention, and its level is equivalent to about $25 \%$ of responsible citizens (people often do not know the name of a congressman representing their interests in Congress. Some people do not know and are not interested in the structure of Government and the participation of citizens in the elections of the state government). He said that in America all laws are executed and judiciary system is powerful. And, though America has no national idea as its territory is home to many nationalities, the Americans respect their country because the state protects the rights of its citizens. This is a background for their patriotism and pride for their country.

In Ukraine, there is a gradual process of civic society development, which is far from being complete. Most of the processes taking place in our society undermine the credibility of the government. The problem of civic education low efficiency in Ukraine lies primarily in the features of social psychology (Батіщева, 2013). The causes of the problems are: the stereotype that the issue of civic education does not require special attention; the lack of consistency in the curriculum of civic education; the lack of consistency in training and professional development of civic education teachers, sharing positive experience, coordination and monitoring. In Ukraine civic education very often "is seen as synonymous with patriotism" (Ройл, 2008).

The best school of democracy is participation in the democratic society life. It is difficult to "teach democracy when young people see that it does not exist in the state" (Карнаух, 2007). Regulatory approach, which is a basis for a system of civic education in Ukraine, exposes flaws of modern public relations, in particular between the government and the people, it insinuates a deep mistrust of government institutions among young people, which subsequently leads to legal nihilism. This was the reason for the recent events in Ukraine, where young people do not come to terms with arbitrary rule.

Nowadays the process of teachers' "re-socialization", developing teachers' positive attitude to democratic values, readiness to adopt new forms of interaction in social groups is of a great importance (Бойчук, 2011).

\section{CONCLUSIONS}

The analysis of the USA experience of youth civic education creates opportunities for implementation of educational projects in Ukraine developing standards of civic education, strengthening the role of NGOs in providing out-of-school education. Civic education enables young people to enter the space of civil society, to take a more active role among their peers, to form the ability and competence to live in a democratic civic society.

Today there is a need in Ukraine to build an effective system of civic education, which would unite the various public and non-governmental institutions.

\section{REFERENCES}

1. New Lens. (2015). Retrieved 2.05.2015 from : http://www.newlens.info/index.html.

2. The Intersection. (2015). Retrieved 2.05.2015 from : http://baltimoreintersection.com/. 
3. Батіщева, О. (2013). Громадянська освіта як інструмент формування громадянського суспільства в Україні : проблеми та шляхи їх подолання [Civic educaton as a tool of civic society formation in Ukraine: problems and their solutons]. In: Актуальні проблеми громадянської освіти: украӥнський та зарубіжний досвід: матеріали Першої науково-практичної конферениї [Proceedings of First Scientific-Practical Conference "Topical Problems of Civic Education: Ukrainian and Foreign Experience"]. Острог : ГО Центр демократичного лідерства, Національний університет «Острозька Академія», p. 9-15 (in Ukranian).

4. Бойчук, М. (2011). Запровадження громадянської освіти в Україні як необхідна умова виховання демократії [Establishment of civic education in Ukraine as a necessary precondition for fostering democracy]. Journal of National Technical Unoversity of Ukraine "Kyiv Polytechnic Institute”. Psylosophy, Psychology, Pedagogy, No. 1, p. 26-30 (in Ukrainian).

5. Геринг, Дж. (2013). Нові потреби громадянської освіти американського суспільства (перекл. Ольга Батіщева) [New Needs of Civic Education (translated by O. Batishcheva)]. In: Актуальні проблеми громадянської освіти: український та зарубіжний досвід: матеріали Периої науково-практичної конферениії [Proceedings of First Scientific-Practical Conference "Topical Problems of Civic Education: Ukranina and Foreign Experience"]. Острог : ГО «Центр демократичного лідерства, Національний університет «Острозька Академія», p. 219-221 (in Ukranian).

6. Карнаух, А. (2007). Громадянська освіта як засіб формування політичної культури молоді [Civic Educaton as a Means of Youth Political Culture Formation]. Політичний Менеджемент [Political Management], No. 6, p. 82-88 (in Ukranian).

7. Ліхневська, Т. (2009). Громадянське виховання учнівської молоді США [Civic Education of]. Abstract of thesis for PhD in Pedagogical Sciences. Тернопіль, p. 19 (in Ukrainian).

8. Міністерство освіти і науки України. (2015). Конщепція національнопатріотичного виховання дітей та молоді [Concept of national-patriotic education of children and youth]. Київ : Міністерство освіти і науки України, p. 13. Retrieved 29.05.2015 from : http://mon.gov.ua/activity/education/reforma-osviti/konczepcziyanaczionalno-patriotichnogo-vixovannya-ditej-ta-molodi.html (in Ukrainian).

9. Ройл, Д. (2008). Виклики для громадянської освіти в Украӥні [Challenges for civic education in Ukraine]. Retrieved 1.05.2015 from : http://osvita.ua/school/school_today/1793/. 